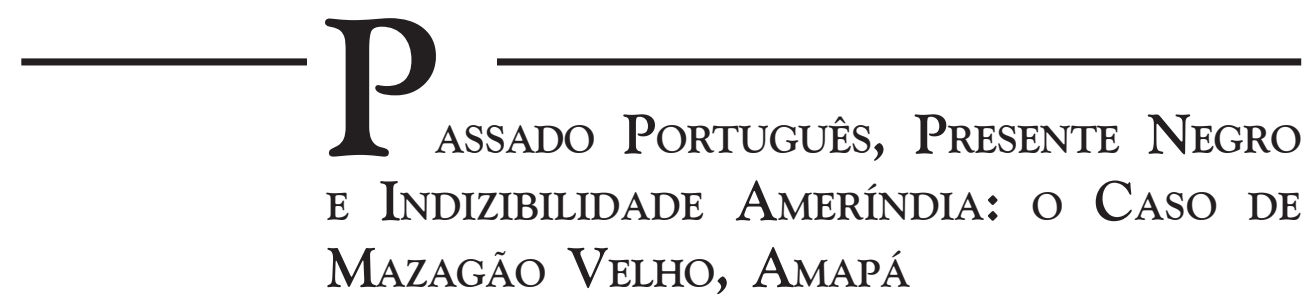

Véronique Boyer

Ao reconhecer por lei o caráter multicultural e pluriétnico da nação, a Constituição de 1988 marca uma ruptura importante com a ideologia dominante anterior, que sustentava a idéia de uma miscigenação cultural e biológica bem sucedida e harmoniosa. A partir dessa data, o Estado admite oficialmente que o período da colonização e da escravidão causou sofrimento intenso a segmentos particulares da população e que esses crimes do passado deixaram seqüelas hoje. Atesta isto o fato dos descendentes de escravos estarem entre os mais pobres e os povos indígenas terem as suas terras e suas culturas ameaçadas. As novas orientações visam, então, elaborar políticas públicas para compensar e reparar os danos junto às vítimas da violência que se encontram por isso marginalizadas: os "índios" e os "negros" ${ }^{1}$ terão acesso a direitos diferenciados nas áreas da saúde, da educação e do território.

Nesse novo quadro, onde está afirmado que a luta contra a desigualdade social passa pela promoção de grupos "étnicos" ou "raciais", a implementação desses programas depende, em primeiro lugar, de um trabalho de identificação das populações às quais se aplicarão. Entre os critérios considerados, uma atenção especial está sendo dada às produções culturais enquanto símbolos de identidades especificas - uma preocupação que vai ao encontro do discurso das instancias internacionais sobre o "valor da diversidade cultural". 
Essa mudança do olhar do Estado sobre o corpo social - e do tratamento que o primeiro pretende aplicar ao segundo - não fica sem efeitos sobre populações que, durante muito tempo, viram-se obrigadas a aproximar-se do modelo do "branco", entendido aqui enquanto figura do dominante português. Para estas, trata-se agora de compreender e situar-se em relação a um discurso oficial incentivando as pessoas e os grupos a regressar a suas supostas origens. Pois a integração a programas dirigidos às minorias implica identificar-se e ser identificado a uma delas: para fazer valer o seu reconhecimento enquanto índios ou "quilombolas", os grupos são então encorajados a dar relevo a certas práticas culturais que se ajustam às categorizações do Estado.

Como é recebida essa nova leitura do social e como ela é incorporada à maneira pela qual os grupos se representam e apresentam aos seus interlocutores institucionais as suas histórias coletivas e individuais? Pode-se supor, de uma maneira geral, que isso leva a uma afirmação mais "livre" e mais assumida da sua identidade - já que ser índio ou negro é valorizado -, bem como a uma melhor integração social - em razão dos bens e serviços ou vantagens aos quais dão acesso os programas. Contudo, deve-se convir que certas situações podem ser mais complexas, para não dizer mais problemáticas.

Com efeito, vincular-se a uma única categoria exige submeter-se a um processo de "desentrelaçamento" de diversas "raízes" ou genealogias principalmente branca, indígena e negra. Considerando esse processo, duas perguntas relacionadas vêm à mente. Qual é, em relação à genealogia eleita como a referência principal, o lugar simbólico atribuído às outras que os grupos reconhecem eventualmente, mas que doravante devem ser postas num plano secundário? E o que acontece com as práticas culturais, sejam elas próprias a um grupo social ou compartilhadas por boa parte da população, quando apreciadas enquanto signos de "identidades étnicas" específicas e diferenciadas? Deveríamos aí integrar à análise a dimensão religiosa das ditas práticas culturais. De fato, não é raro as expressões religiosas, por exemplo dos cultos afrobrasileiros mas também do catolicismo popular, serem vistas como manifestações culturais de grupos sociais específicos. Nessa perspectiva, o religioso se sobrepõe à cultura, comprovando a diferença. Porém, essa lógica não é sempre aquela que sustenta o ponto de vista das populações e é possível, como veremos, que, buscando a afirmação da sua distinção, estas estejam levadas a trabalhar a fronteira entre religião e cultura no sentido de as separar.

Todas essas indagações implicam tomar em consideração, além da forma como um grupo se pensa e afirma a singularidade de certas produções culturais e/ou religiosas frente à sociedade mais ampla - numa abordagem bastante clássica -, o impacto da nova interlocução com o Estado na negociação de um espaço de representação por populações histórica e sociologicamente dominadas. Em outros termos, o que nos interessa aqui são os processos de identificação operados 
na interação com as categorias veiculadas pelos representantes dos poderes públicos, e não as "identidades substantivas" das populações, apreendendo, desta forma, o "étnico" como uma relação social entre outras.

Discutiremos essas questões a partir do exemplo de uma vila situada a aproximadamente sessenta quilômetros de Macapá, capital do Amapá, que é considerada por todos (representantes das instituições, dos movimentos sociais, etc.) como o "berço da cultura" amapaense: o lugar onde elementos "de fora" sedimentaram-se, formando uma "cultura própria" que depois se irradiou por todo o Estado. Na verdade, esse "berço" é duplo. De fato, Mazagão Velho remonta sua ascendência a duas genealogias distintas reunidas pela história da colonização da Amazônia. Por um lado, é de conhecimento geral que a fundação da vila data da vinda dos Portugueses no século XVIII e que a celebração da festa de São Tiago começou nessa época. Por outro lado, a vila aparece como o lugar através do qual os negros afirmaram sua presença no Estado, trazendo com eles a dança do marabaixo. Essa narrativa sobre um enraizamento profundo no passado demonstra uma consciência aguda da dimensão histórica no povoado, relativamente rara numa região onde a maioria da população se caracteriza mais pelo extenso reconhecimento dos parentes colaterais (Lima \& Alencar 2001) do que pela invocação da ancestralidade como critério de autoctonia.

Negros e "portugueses" estão unidos no discurso pelos seus esforços insistentes para realizar a façanha de construir, a partir de nada, uma vila no meio da selva amazônica. Aliás, as marcas culturais deixadas por uns e outros são sinais fortes de que o "enxerto" funcionou. Todavia, eles não ocupam o mesmo lugar na narração. Pois se os Mazaganenses situam-se nessas duas genealogias, operam um ordenamento entre elas que as transforma em dominantes sucessivas da sua longa história: o passado seria inegavelmente português, mas o presente seria incontestavelmente negro. Uma pergunta surge então, com ainda maior acuidade devido ao fato do povoado encontrar-se na região de mais densa concentração da população indígena do país: como entender que o índio, figura da autoctonia por excelência, não apareça nessa retórica visando a estabelecer o caráter remoto da existência da vila?

Para tentar encontrar alguns elementos de resposta, examinaremos, para cada filiação simbólica reconhecida pelos habitantes, os elementos indicados como significativos, no intuito de mostrar como se constrói essa representação peculiar onde a continuidade e o enraizamento se afirmam através de uma substituição assumida da referência genealógica - o que seria, nos termos do Estado e dos militantes, uma mudança da "identidade étnica". Um dos efeitos dessa forma narrativa parece ser o de contornar a obrigação de ter que escolher entre categorias concorrentes (nesse caso, entre português e negro), e esquivarse da concomitante exigência de renunciar a uma delas na definição da sua identidade social. A incorporação enquanto parte de si daqueles que, no quadro 
político atual, são definidos como Outros distantes, embasa-se na transformação das diferentes marcas "étnicas" em "bens culturais", um processo que torna possível a sua apropriação simultânea. Nessa perspectiva, poder-se-á então retornar à questão da ausência do índio ao lado do português e do negro.

\section{Passado português}

A historia do Mazagão Velho é muito longa, é muito grande. Começou quando os Portugueses chegaram do Marrocos no século XVIII.

Segundo informa o historiador Laurent Vidal (2005) ${ }^{3}$, a história de Mazagão começa há mais de três séculos do outro lado do oceano Atlântico, quando, em 1769, a Coroa portuguesa resolve, sob a pressão dos Mouros, retirar-se da costa marroquina. Toma-se então a decisão de mandar as 436 famílias da fortaleza de Mazagão para a Amazônia, que estava sendo colonizada. Entre 1770 e 1776, após demoradas etapas em Lisboa e em Belém do Pará em que se perde quase um quarto do contingente inicial, 313 destas famílias, com os escravos recebidos na capital do Grão-Pará no lugar de soldos, chegam ao lugar onde esperam fundar a Mazagão americana. O propósito desse deslocamento de população é, portanto, ocupar uma região ainda virgem da presença portuguesa, seja com o descimento de índios, seja com a transplantação de colonos. O local escolhido reflete esses dois aspectos da colonização: a construção da vila é planejada onde já havia um aldeamento indígena. Aliás, o arquiteto Sambucetti desenha a planta do Mazagão depois de fazer um mapa topográfico e um levantamento do povoado de Santa Anna. Substituindo habitantes indígenas por soldados portugueses, a coroa entende, de forma patente, consolidar a sua posição frente à cobiça territorial de outras potências.

Os recém-chegados instalam-se num povoado cuja edificação está bem adiantada, graças à mobilização de uma mão-de-obra ameríndia e após a expulsão dos antigos habitantes do vilarejo. Raramente na região, a fundação de um núcleo urbano testemunhou tão claramente uma vontade política (Araújo 1998) e Mazagão apresenta no começo da sua existência amazônica todos os atributos de uma vila colonial: convento, quartel, igreja, intendência. No entanto, abandonada pelos poderes públicos a seu destino, confrontada a um meio ambiente desconhecido, vítima de epidemias mortais e atormentada por lutas políticas internas entre liberais e conservadores, Mazagão passa rapidamente por mais baixos do que altos: em 1833, perde o seu estatuto de vila, e até o seu nome. Pode-se dizer sem ironia que o novo - Regeneração - deu sorte, pois a povoação recupera o seu primeiro nome em 1840 e é mesmo promovida a cidade em 1888. Mas esse momento de melhoria não durou muito, apenas até 1915 quando a 
sede do município é transferida para Mazaganópolis, a, aproximadamente, 30 quilômetros de lá. A vila, doravante conhecida como Mazagão Velho, só virá a sair do seu isolamento com a construção da estrada até o Mazagão Novo (como é habitualmente nomeado Mazaganópolis) nos anos 1950 e, sobretudo, com a sua extensão até Macapá nos anos 1970.

Dessa história, os habitantes do Mazagão Velho, hoje pequeno povoado em torno de duas mil almas ${ }^{4}$, conhecem as linhas gerais. E não perdem uma ocasião de insistir sobre a sua origem remota - no tempo e no espaço - e a sua grandeza passada: "A vila foi muito grande, mas hoje não se vê mais nada". O que ainda se vê é um casarão que foi dividido entre os descendentes da família Ayres, certas paredes passando de taipa a madeira e o chão de parquê a lajota à medida das reformas. $\mathrm{O}$ que também indica essa ocupação portuguesa antiga, são as ruínas da "igreja velha", escavadas em 2004 por uma equipe da universidade de Pernambuco, coordenada pelo arqueólogo Marco Albuquerque (2004), para aonde são levados os turistas. Todavia, para a população, o sinal o mais eloqüente desse passado português é a festa de São Tiago, celebrada desde 1777, durante a qual é encenada a luta dos mouros e dos cristãos que se encerra, é claro, com a vitória destes últimos.

A festa realizada durante o mês de julho é o momento "da volta dos filhos do Mazagão" que, por causa de estudos ou de trabalho, foram morar na capital ou na sede do município. Nessa ocasião, a vila parece desabrochar: as casas se enchem de gente, as ruas de camelôs, os barzinhos fechados o ano todo abrem suas portas, barracas vendendo comida são montadas em qualquer canto. Por outro lado, a infra-estrutura melhora consideravelmente: ambulância, médico e remédios são postos à disposição, veneno contra mosquito é jogado, etc. Pois desde os anos 1990, Mazagão Velho recebe, além de doações particulares, verbas importantes da prefeitura e do governo do Estado para a organização do evento.

Se a comemoração estende-se sobre doze dias (16-28 de julho), poucos são aqueles que participam do seu desenrolar completo (programação esportiva, baile da terceira idade) e assistem às novenas. A animação começa verdadeiramente na noite do dia 24 quando, no baile de máscaras, os homens, fantasiados de mulher e o rosto encoberto, encenam o momento em que os cristãos, introduzidos às escondidas num campo inimigo comemorando cedo demais a sua vitória, devolvem aos mouros os presentes envenenados anteriormente recebidos deles. A movimentação atinge seu auge no dia seguinte, 25 , durante a missa e a representação da batalha onde se enfrentam na rua principal os mouros e os cristãos a cavalo ${ }^{5}$. Nesse último dia, o número de pessoas querendo prestigiar São Tiago é tão alto que a população da vila quadruplica. Entre eles, constam jornalistas, fotógrafos, sociólogos e "autoridades": prefeito, antigo e atual governadores, deputados, secretários dos afrodescendentes. Já a festa das crianças, ou dos "pequenos", que repete fase por fase a festa "dos 
grandes", só conta com a presença dos habitantes e parentes mais próximos. Efetivamente, a partir do dia 26, as casas vão-se fechando pouco a pouco, os funcionários da prefeitura procedem à limpeza das ruas e a vila retorna a sua vida pacata.

A afluência de pessoas movidas por motivos diversos (econômicos, eleitorais, turísticos, familiares) muda momentânea, mas radicalmente, as feições do povoado. A festa é portanto uma fonte incontestável de prestígio e a transformação da vila nessa época - impressionante para quem a presencia pela primeira vez - é acompanhada por uma grande visibilidade de Mazagão através de matérias nos jornais, rádios e televisão. Por isto, os habitantes não hesitam em compará-la a um milagre ou a uma benção que vai se repetindo a cada ano: "O Natal está em julho."

O reconhecimento social que a celebração de São Tiago proporciona está fundamentado na crença de que, nessa vila, atualiza-se regularmente um legado dos primeiros habitantes a seus legítimos depositários. Autenticidade, fidelidade e tradição são assim as noções-chave do discurso. De fato, os mazaganenses são muito apegados a essa herança recebida dos antigos e julgam-na totalmente sua. Todavia, paradoxalmente, consideram ao mesmo tempo que o passado ao qual remete é obsoleto do ponto de vista da filiação biológica. É assim comum ouvir dizer que os iniciadores da festa teriam deixado poucos descendentes na praça. A explicação dada é que, dispondo de mais condições do que o resto da população para fugir das epidemias que, várias vezes, atingiram o povoado no século XIX, foram embora para a capital ou para a sede do município. À medida que certa intimidade se cria com a pesquisadora, os habitantes do povoado evocarão eventualmente um bisavó ou um tataravó que foi proprietário de escravos. Mas, de entrada, a grande maioria não se afirma como filhos, netos ou bisnetos de portugueses.

\section{Presente negro}

A civilização entrou por Mazagão Velho. Somos da raça africana. O marabaixo é uma manifestação cultural que vem do Marrocos. Não é ramo; é raiz.

Hoje em dia, boa parte da população se declara descendente dos africanos que chegaram junto com os portugueses. Os habitantes ligam portanto sua história, antes de mais nada, àquela dos negros, escravos ou não, que não tiveram a opção de fugir das epidemias mencionadas acima, permanecendo no lugar. Sabem que os portugueses pobres compartilharam esse destino, mas enfatizam o fato de que acabaram "se misturando", como se no decorrer das uniões o negro tivesse "absorvido" o branco. Sustentam, por outro lado, que 
certos negros conseguiram escapar das doenças, encontrando-se na origem das vilas próximas, algumas sendo fundadas como quilombos. Com essa narrativa, fortalecida com a crença de que o Marrocos é povoado de gente de pele escura, pois está na África, o Mazagão Velho firma-se como vila negra ${ }^{6}$ e coloca-se na origem dos lugarejos vizinhos.

Aqui também, a representação da linhagem combina história, religião e cultura. Com efeito, desta genealogia negra, testemunharia o marabaixo, uma dança a respeito da qual circulam diversas versões, mais complementares do que excludentes. Numa primeira, diz-se simplesmente que ela foi trazida pelos africanos do Marrocos, onde recebia o nome de coco A segunda já propõe esclarecer o porquê dessa substituição, portanto uma etimologia para a palavra. Encontrar-se-ia na decisão de uma velha mulher de chamar o coco de marabaixo, depois de um negro escravo, protestando contra sua deportação, deixar-se morrer durante a travessia e seus companheiros jogarem-no na água, o corpo indo então "mar abaixo". A última narrativa focaliza-se mais na explicação da maneira de dançar o marabaixo: o passo não pode ser leve, mas sim arrastado, pois quando atendeu ao pedido dos negros querendo um dia de folga para festejar o Divino Espírito Santo, "a rainha" mandou tirar as algemas das mãos, porém não dos pés antes de deixá-los subir no barco.

O marabaixo é, desta forma, claramente associado à celebração de uma figura católica, e é principalmente nesta ocasião que ele é dançado. A festa tem uma duração quase tão comprida (16-26 de agosto) quanto a de São Tiago, comportando um ciclo de novenas e várias alvoradas de madrugada. Como em outras partes do Brasil, desenrola-se em torno da coroação da imperatriz cercada das suas "empregadas", do sorteio das figuras para o outro ano, o início e o fim da festa sendo marcados pelo levantamento e a derrubada do mastro. A organização da festa do Divino Espírito Santo depende por inteiro da boa vontade dos habitantes; não aparecem turistas, nem "autoridades", à exceção de alguns militantes negros, e os raros visitantes são parentes do Mazagão Novo. Por essas razões, a comemoração de agosto é dita como sendo "mais da comunidade" do que a de julho. A animação está no auge no dia 23 à noite, durante o baile que abre com marabaixo para depois continuar no "som mecânico", e no dia seguinte quando as mulheres - vestidas de um saião próprio para fazer evoluções -, bem como os homens e as crianças, deslocam-se da manhã até o fim da tarde de casa em casa, sendo-lhes oferecidos comes e bebes. Um carreteiro acompanha a procissão com um tonel de gengibirra, bebida feita de abacaxi, gengibre, cachaça e açúcar. De uns dez anos para cá, aqueles que ainda agüentam podem continuar no marabaixinho que acontece ainda nas ruas no dia 25 e nas casas particulares no dia 26.

Sobre a relação entre a festa católica e a dança, as leituras são diversas e até divergentes. Alguns afirmam tratar-se de uma "manifestação negra num 
espaço branco". Outros sustentam que a celebração do Divino Espirito Santo situa-se "dentro" do marabaixo. Outros ainda, certificando que a dança sempre ficou "fora" da religião da igreja, declaram que é uma festa profana para homenagear um santo. As interpretações variam, portanto, da absorção do branco pelo negro, ou do negro pelo branco, a uma tentativa perceptível de separar os dois universos.

Apesar desses agenciamentos diferenciados entre o que seria do "branco" e o que seria do "negro", um fato é seguro. Hoje, o marabaixo é um referencial essencial para o Mazagão Velho: é o selo da autenticidade presente da genealogia negra, da mesma forma que a "batalha" é considerada como a prova legítima de um passado iniciado pelos portugueses. Todavia, se o Mazagão Velho sempre se orgulhou do seu legado português, a sua consciência negra é recente, datando do fim dos anos 1990: "Antes, os velhos não falavam em tradição. Antes era o dia a dia. Ninguém se preocupava em cantar a história do povo negro". O slogan impresso sobre algumas camisetas, proclamando que "o marabaixo não é rama, é raiz", confirma que, durante muito tempo, a dança apareceu como uma manifestação cultural secundária, uma simples lembrança que escravos vieram da África para a Amazônia. ${ }^{7}$

O material colhido sugere que a representação negra do Mazagão Velho atual se deu através de um processo duplo: a construção da indissociabilidade do marabaixo e da festa do Divino e a inversão da ordem de importância entre ambos. Com efeito, até nos anos 1930 (i.e., bem depois do fim das epidemias, quando os portugueses já teriam indo embora), existia, em maio, uma comemoração dita "dos brancos" sem a dança. Com o seu desaparecimento, só continuou a festa "dos morenos" ou "dos pardos", em agosto, na qual o marabaixo acompanhava a celebração do Espírito Santo. Após um período de desafeição nos anos 1950-60, a festa é reativada localmente por um grupo de senhoras. Dizem os habitantes que é nesse momento que a gengibirra fez a sua aparição, ninguém sabendo mais preparar o aluá de milho verde. Nos anos 1990, a dança, e não a festa do Divino, recebeu um novo impulso quando alguns integrantes das novas gerações mostrar-se-iam preocupados com "a falta de interesse dos velhos em transmitir as tradições”. Essa mudança na liderança - dos velhos para os jovens - trouxe repercussões para o marabaixo: entre outras, as crianças obtiveram o direito de participar, a roupa ficou "padronizada" e novos passos (geralmente do carimbó, mais animado) foram incorporados. $\mathrm{O}$ fortalecimento da identificação com a genealogia negra ocorreu nessa época, quando o produtor de uma banda da capital incentivou o grupo em gravar um $\mathrm{CD}$, o que será feito em 1999. Abriram-se, a partir daí, possibilidades de "mostrar" o marabaixo paralelamente às outras festas católicas no Mazagão Velho, bem como em espetáculos organizados em Macapá no espaço concedido pelo governo Capiberibe à União dos Negros do Amapá (UNA). 


\section{Uma tentativa persistente de separar a religião da cultura}

Se os habitantes reconhecem que tanto a festa de São Tiago quanto o marabaixo são ligados a uma celebração católica, considerando cada parte como indispensável ao sucesso da outra, estão também empenhados em tentativas para determinar uma diferença entre esses elementos contíguos e para pensar a sua natureza. Percebe-se uma preocupação análoga em definir limites entre, por um lado, o aspecto propriamente religioso, i.e. a missa e as novenas, e, por outro, os eventos ocorrendo fora do espaço ritual, isto é, a batalha ou a dança.

No caso do marabaixo, o termo contraposto ao de "religião" é geralmente o de "profania". Com essa noção, indica-se que a dança não tem finalidade sagrada. Mesmo durante as alvoradas, quando é realizada nas paradas em frente ou dentro das casas das festeiras onde se encontram altares com figuras de santos, não deixaria de pertencer ao domínio secular. $\bigcirc$ consumo de álcool, fortemente aconselhado, é apontado como um dos elementos incompatíveis com aquilo que a população entende por atitude apropriadamente religiosa. No entanto, o grupo do marabaixo encarrega-se também de certas atividades (torrefação do cacau, bolo do Divino, etc.), remetendo diretamente ao preparo da festa católica, fundamentais para a sociabilidade dos seus integrantes. Logo, a celebração do Divino acaba sendo tão essencial para definir o marabaixo quantos os comportamentos festivos mencionados. Constitui-se desta forma um continuum do lado religioso "branco" até o lado profano "negro" sem ruptura marcada, comportando apenas interpretações diversas e matizadas de como os dois se relacionam.

No caso de São Tiago, a distinção se efetua em termos próximos de "religião" e "cultura", mas o processo leva à construção de uma oposição muito mais rígida, a partir da qual se defende a definição de esferas de ação autônomas e de posições antagônicas no campo social local. Assim, a religião seria da responsabilidade do ministro da eucaristia, representante local do padre, que exerce a sua autoridade entre as paredes da igreja e em áreas onde momentaneamente se executam atividades religiosas, como o palco erguido para a missa no dia 25 de julho. Quanto à cultura, remeteria a tudo o que acontece na parte exterior do edifício católico. Nessa divisão, a "batalha" realizada nas ruas encontra-se subtraída do domínio da instituição eclesiástica e dos seus delegados. Desta parte "leiga", a Associação Cultural da Festa de São Tiago, recém formada $(2005)^{8}$ e devidamente registrada no cartório, pretende assumir o controle. De certa forma, pode-se dizer que a "batalha" teve mais êxito do que o marabaixo do ponto de vista da sua emancipação da dimensão religiosa.

Portanto, na mesma vila, o trabalho visando decompor práticas religiosas comparáveis - na medida em que as duas comportam manifestações situadas dentro do espaço católico e outras fora dele -, para distribuir os elementos 
identificados em classes diferentes, tem conseqüências opostas. Num caso, permaneceu um sistema aceitando variações e acomodações enquanto que, no outro, gerou - ou traduziu - intensos conflitos. Não se pode atribuir a aparição da discordância somente à diferenciação mais ou menos avançada das instituições locais encarregadas da organização dos eventos. Com efeito, a transformação do legado português num bem cultural, argumento principal para arrancá-lo do ritual religioso, é também um fenômeno presente no caso da herança negra: o grupo da dança tem na Associação Raízes do Marabaixo, constituída há uns oito anos, um instrumento equivalente à Associação Cultural da Festa de São Tiago. Além disso, as duas atuam tendo por lema a necessidade de "valorizar a cultura que é nossa".

O que chama aqui atenção é que o conflito surgiu em torno da oposição entre sagrado e profano quando a discussão ficou no âmbito de uma única genealogia, e não quando se tratou da relação entre duas linhagens reconhecidas como distintas. Apesar do andamento da pesquisa não autorizar ainda responder por inteiro, algumas perguntas merecem desde já ser levantadas. Será que o grau de operacionalidade do trabalho para separar a religião da cultura se explica pelo lugar específico ocupado por esses discursos sobre as práticas rituais? É possível, nesse caso, considerar que a razão principal reside nos imperativos particulares aos quais cada um deles está submetido? De fato, o marabaixo e a festa de São Tiago diferem pela posição que lhes é atribuída na representação do grupo. O marabaixo corresponde a uma narração sobre si mesmo para os dias de hoje. A singularidade social é enunciada num registro "étnico", um "nós" diferente do mundo de fora, e até em oposição à sociedade dominante. $O$ discurso sobre São Tiago não está sujeito ao mesmo tipo de exigências, já que a festa é associada a uma genealogia que não é aquela que os habitantes reconhecem para si. Trata-se aqui de ser reconhecido como legítimo depositário de um patrimônio representando aquele que é definido como o Outro. A afirmação da distinção da vila não diz respeito a uma identidade diferenciada por natureza, mas sim a uma exclusividade detida pelo povoado sobre uma parte da cultura do "branco" português. A dimensão reflexiva se concentra desta vez sobre o que o povoado ("nós") já foi no passado.

A observação nos incita a levar em consideração o tipo de representação populacional atribuído pelo Estado a esses "bens" enquanto símbolos de identidades específicas: a festa de São Tiago é tida como a maior e a mais antiga manifestação cultural popular do Amapá ${ }^{2}$, enquanto, por sua vez, o marabaixo é associado ao talento e à memória de um segmento particular da população, i.e., os negros. A primeira conta portanto com um poder de identificação maior por parte da população e de um respaldo incomparável em termos de prestígio. Não é um acaso que a festa de São Tiago apareça como o símbolo do Estado, o que se reflete na vinda das "autoridades" e num 
financiamento crescente pelos poderes públicos estaduais e municipais conscientes das suas eventuais conseqüências políticas. Para o Mazagão Velho, a genealogia portuguesa tornou-se literalmente sinônimo de riqueza simbólica e, embora limitada, material. A interferência cada vez maior do "exterior" na festa de São Tiago é provavelmente um dos motivos do surgimento de pontos de tensões fortes e de conflitos de interesses entre diversas facções na vila. $O$ desentendimento, e até a briga, entre a diretoria da igreja e a associação cultural, que se coloca como o legítimo receptor do benefício material da sua organização, corresponderia a tentativas de controlar a recepção desses recursos em nome da "comunidade". Seria desta forma um efeito sociológico.

Voltando ao marabaixo, é possível sugerir que, por comparação, a dita identidade negra, apesar de reconhecida pelas autoridades e hoje reivindicada pelo grupo, permanece secundária, particularizada para não dizer marginal, numa sociedade cujo referencial principal continua sendo a figura do branco português. No fundo, o statu quo é mantido. Pois paradoxalmente, apesar de alguns habitantes certificarem que os universos negro e português se mantêm separados, a justificação última da prática da dança negra encontrar-se-ia no pólo do qual a princípio se esperava que quisesse se autonomizar: a religião do colonizador português. Festa profana, o marabaixo é concebido como uma homenagem feita a um santo católico e a sua estrutura - o seu roteiro, o seu ritmo - lhe é dada pela celebração do Divino. Aliás, as estórias em torno das condições da participação dos escravos à festa, preenchendo o papel de mito fundador, reforçam essa associação íntima. Sem a cerimônia católica, o marabaixo seria um carnaval fora de época, um mero espetáculo folclórico que não permitiria a atualização eficaz - isto é, que lhe conferisse uma indiscutível dimensão sagrada - da afirmação de uma identidade singular. A genealogia negra simbolizada pelo marabaixo permanece assim amarrada em todos os casos ao universo de referência português e a suas festas católicas. No máximo, a relação hierárquica pode ser afrouxada, a sua ordem sendo aparentemente revertida para fazer do catolicismo um pretexto.

A situação do marabaixo, no entanto, pode vir a mudar, com a atuação do governo através da secretaria dos afrodescendentes, que atribui verbas para a organização das festas, e a difusão do discurso sobre o patrimônio imaterial, oferecendo outras fontes de recursos. Novas perguntas surgem então. Será que a organização de espetáculos de marabaixo na capital, a gravação de CDs e os trabalhos de inúmeros estudantes e pesquisadores documentando e comprovando a identidade negra do Mazagão Velho modificarão substancialmente a representação atual de uma sociedade branca com encraves negros limitados? Qual é o risco de levar a uma mera folclorização da dança, deixando de considerála com o devido sério como uma entrada propícia para entender as diferentes dimensões da vida social (não somente cultural ou religiosa mas também econômica, política, etc.)? Não devemos temer, nesse caso, que, mais uma vez, 
sejam reconduzidos certos aspectos da imagem do negro (fútil, brincalhão, etc.), condenando as pessoas a se espelhar no estereótipo apresentado a elas pela sociedade dominante? E quais serão as incidências desse processo sobre as relações entre os moradores de uma vila "negra" e outros habitantes da região, às vezes parentes, associados a outras categorias - ou a nenhuma?

\section{Indizibilidade ameríndia}

No contexto de uma polarização entre, por um lado, branco, português, passado e, por outro lado, negro, africano, presente, a figura do índio é totalmente excluída. Apesar da vila ter sido construída no antigo sítio de um aldeamento indígena por uma mão-de-obra ameríndia e embora, quando solicitados, os habitantes indicarem elementos atestando esta ocupação (traços de malocas, lembrança de taperas abandonadas, pedaços de cerâmica, etc. ), não se conserva uma memória vivaz de encontros e trocas. No que tange a histórias familiares, poucos no Mazagão Velho são aqueles que mencionam um ancestral indígena. Entre eles, está a Dona Maria Barriga que fala de uma avó materna tapuia, e de um bisavô "índio". Outra exceção é Rozicema que sabe que seu pai "vinha dos índios" e que o seu avô paterno era "índio mesmo". Por fim, a Dona Olga diz que sua avó materna era mameluca, sem que saiba, diz ela, o significado do termo; o que tem certeza, no entanto, é que tinha a pele clara. Para o resto da população, os índios, cuja existência se reconhece num passado remoto, sempre se mantiveram à distância, morando na beira dos rios ou afastando-se na floresta à medida do avanço dos brancos e dos negros.

Para entender o porquê dessa escassa referência numa região que concentra a maior porcentagem de populações indígenas do país, é preciso considerar as representações geralmente associadas ao "índio". A opinião de uma funcionária do Museu Sacaca (museu encarregado de divulgar as pesquisas realizadas pelo Instituto de Estudos e Pesquisas Científicas e Tecnológicas do Estado do Amapá - IEPA) em Macapá receberia, sem dúvida, a adesão dos habitantes do Mazagão Velho: "Fico chocada dos paraenses verem a gente como índios. Ninguém quer ser índio. Os preconceitos do pessoal do Sul, a gente espera, mas não do pessoal do Norte. Somos todos nortistas". Neste discurso, a vítima do preconceito não é o índio com o qual ninguém quer ser confundido, mas o nortista amalgamado ao índio, como se esse fato em si fosse o supremo ultraje.

As razões da rejeição tornam-se compreensíveis levando em conta as descrições do que é ser índio para os habitantes do Mazagão Velho: "o índio come carne crua, anda sem roupa"; "a gente não entende ele"; "é esquisito, brabo, perigoso"; "é um bicho do mato". O índio, afirmam em substância, diferencia-se deles na língua, nos hábitos e na moradia. Ora, os traços usados para caracterizá-lo desenham o que seria o pólo oposto de uma humanidade 
falando a mesma língua, comendo alimentos cozidos e morando em povoados. A representação do ameríndio enquanto selvagem vivendo longe da vila, nas "reservas", coincide dessa forma com a figura do Outro por excelência, afastando qualquer possibilidade de imaginar um eventual elo entre eles e nós: uma identificação positiva a ele ficou inconcebível. Com toda certeza, a população indígena sofreu das doenças e as guerras trazidas pelo colonizador. Mas, na verdade, "sumiu" também devido à política assimilacionista dos governos sucessivos. Por exemplo, numa vontade deliberada de povoar os seus novos domínios, a Coroa portuguesa, no século XVIII, proibiu o uso do termo caboclo para designar os filhos da união entre ameríndias e portugueses (Guzmán 2006:74), estes tendo sido incluídos na categoria branco: a "brancura" desta forma predominou sempre frente à "indianidade".

O projeto dos dominantes para os africanos e seus descendentes foi outro: antes da abolição, marcar uma diferença irredutível para justificar a sua escravidão, e depois dela, mandá-los de volta ao continente de origem ou diluir a presença negra com a importação de um contingente europeu. A ascensão social, resultando na integração à categoria branca, deu-se aqui através de estratégias matrimoniais e esforços individuais, a necessidade econômica (a produção e a reprodução da sociedade) prevalecendo sobre os interesses políticos (superestimar as estatísticas de povoamento). No entanto, é provável que, durante o período pré-abolicão, vigorou, para os filhos de negros com índios, um sistema análogo de absorção dos segundos pelos primeiros para manter o contingente de mão de obra escrava.

Já que, para as autoridades, a "indianidade" sempre foi subjugada pela "brancura" ou pela "negrura", o retrato do país acabou saindo essencialmente em branco e preto. Pode-se então perguntar em qual medida, quando os mazaganenses falam dos seus parentes mortos, de pele clara como brancos - e até daqueles de pele escura como negros -, não subsistiria algo assim como um eco dessas políticas, formais ou informais, do passado?

Seja lá como for, no contexto atual da reivindicação da genealogia negra, o problema para os habitantes da vila não é a "selvajaria" dos seus ascendentes, mas sim o do seu estatuto social numa vila que todos sabem ter sido um lugar de escravidão, numa época triste e difícil. Nesse ponto, é notável que os mazaganenses tendem a minimizar os maus-tratos e o sofrimento causado a seus parentes. Declaram muitas vezes que os donos trataram "com dignidade" os seus escravos, sublinhando que a maior parte deles foi "doméstica" e não "braçal". Atrás dessa diferença de atividade econômica, uma tida como mais leve que a outra, desenha-se uma configuração espacial que corresponde a uma representação da organização social centrada na casa do português dominante. A partir dos portugueses que têm o controle do lar, vêm primeiro os escravos domésticos encarregados da sua manutenção, segundo os escravos braçais, na 
roça, fornecendo o necessário para alimentá-lo, e por fim os índios, no mato, sem contato nenhum com ele. Nesse sistema hierarquizado, a casa do português aparece, implicitamente e provavelmente de modo inconsciente, como o locus da definição do que se julga apropriado e como o padrão do estado de civilizado. $\mathrm{O}$ grau de desenvolvimento supostamente atingido pelos diferentes grupos sociais coincide com a distância geográfica em que estão situados em relação a ela.

Nessas circunstâncias, ao dizer que a maior parte dos "nossos" ancestrais parentes foram escravos domésticos, os habitantes do Mazagão Velho parecem tomar uma distância com os negros "da roça", que estão situados nos escalões inferiores da "civilização", e com os índios por sua vez colocados na sua margem, numa extra-humanidade. Alguns depoimentos, enfatizando o fato da grande maioria dos negros ter vindo do Marrocos já "libertos", parecem creditar essa hipótese de uma definição de si por identificação ao modelo do português. Com efeito, com esta suposta liberdade, os primeiros negros africanos que trouxeram o marabaixo ao Mazagão Velho encontram-se em pé de igualdade com os desbravadores portugueses que implantaram a festa de São Tiago. À diferença do índio que, apesar de livre, é associado ao "selvagem", o negro, embora descendente de escravos, é considerado "civilizado". É portanto possível situarse na genealogia que representa.

É verdade que há certas pessoas nas proximidades de Mazagão Velho a quem se atribui hoje em dia uma ascendência indígena: são os ribeirinhos espalhados pelos arredores, que vêm às vezes morar na vila e que podem ser parceiros matrimoniais. Entretanto, com a integração no discurso que já não há mais "índios de verdade", ao lado do episódio da partida dos portugueses, os indivíduos oriundos dessas famílias acabam aderindo à genealogia "negra" do Mazagão, assim que laços de parentesco são estabelecidos: "Sou clara, meus pais não são daqui. Mas nasci na $\mathrm{Foz}_{\mathrm{oz}}$ (do rio) e me considero mazaganense. Então sou da raça negra. A gente não sabe explicar por que nossos pais não falavam disto" (Maria Grande). A genealogia negra consolida-se desta forma cortando a linhagem do português e mantendo a exclusão do índio.

Apesar da configuração atual centrada na linhagem negra, alguns elementos sugerem que à figura do índio poderia ver-se atribuir um lugar no panteão local, ao lado dos fundadores portugueses e ancestrais negros. Um exemplo é o projeto da Associação Raízes do Marabaixo de "reativar" outra dança, o sairé ${ }^{10}$, que deixou de ser praticada nos anos 1970: "A nossa intenção é colocar novamente o sairé como um movimento forte na nossa cultura. Devemos prestigiar e valorizar essa comunidade." Ora, o sairé é geralmente considerado pelos habitantes como uma "dança de índios". Alguns deles sustentam que foi inclusive trazida ao Mazagão Velho por "pessoas experientes", expressão usada a respeito de quem tem competência em pajelança. Se hoje em dia, o trabalho com os encantados não é associado a uma genealogia particular, o uso de pena e maracá é suscetível 
de constituir-se num signo suplementar para alimentar um eventual discurso sobre a "indianidade". Não há dúvida de que a reativação dessa dança "indígena" modificaria de modo significativo a imagem que o povoado tem dele mesmo e que oferece ao resto da sociedade. Caso essa hipótese se concretize, resta saber qual será o modelo escolhido para essa nova genealogia: o da batalha, com uma separação entre filiação biológica e herança cultural, ou da dança negra, com uma sobreposição das duas?

\section{Conclusão}

Pudemos observar que mudando de época - de outrora para agora -, os mazaganenses trocam de linhagem de referência ou, pelo menos, de genealogia, para definir-se. Nas narrações, os portugueses e a festa de São Tiago ocupam um lugar significativo no que diz respeito ao passado, ao passo que os negros e o marabaixo aparecem como elemento determinante no que tange ao presente. De fato, unanimemente reconhecida como o "berço da cultura negra" no Amapá, a vila foi incluída entre os povoados que, há poucos anos atrás, a superintendente do Incra/AP, ela própria militante do movimento negro, quis integrar aos programas dirigidos aos quilombolas. Durante o debate, os defensores da proposta alegavam que, desta forma, o Mazagão conseguiria mais recursos, outros argumentavam a necessidade de defender-se da "invasão" pelos ribeirinhos. No entanto, a maior parte da população assegurou que os seus ancestrais não foram quilombolas ("nunca foram foragidos ${ }^{11}$; vieram para morar") e que, com o novo estatuto, "a vila ia parar de crescer, já que ninguém poderia mais construir casa" lá. Contradizendo as previsões, os habitantes do Mazagão Velho não aceitaram se tornar quilombolas.

Essa recusa explica-se em parte pelo descompasso entre o modo pelo qual o Estado define grupos de populações, cujo resultado é a criação de categorias estanques, e as representações locais relativas à singularidade da vila, combinando de modo flexível os registros da história e cultura, do passado e do presente. Pois se a dança adquire um inegável destaque, não significa que venha substituir a batalha. Apesar de pertencer à linhagem portuguesa na qual poucos se reconhecem do ponto de vista da filiação, a "batalha" é considerada, pelos habitantes de uma vila percebida como o exemplo paradigmático de uma comunidade negra rural, como cultura "nossa", i.e., como fundamento de identidade. Na realidade, trata-se mais de uma tonalidade dada ao discurso sobre as origens em função de um contexto de enunciação. Essa maneira de lidar com a história, ordenando as genealogias portuguesa e negra como dominantes sucessivas e enfatizando de modo cíclico várias facetas, está na origem da reputação do Mazagão Velho. Aliás, o ministério da cultura propôs reconhecer a vila como comunidade remanescente de quilombo após o secretário nacional da identidade e da 
diversidade cultural, na época o ator Sérgio Mamberti, presenciar a festa de São Tiago em 2003. "A cidadania é só em julho": a declaração irônica desse morador confirma a sua importância para o povoado. Com efeito, é a celebração efetuada sob o signo do português que, proporcionando uma visibilidade eficaz embora momentânea, permitiu chamar a atenção das autoridades para os negros realizando o marabaixo, fornecendo assim a oportunidade de fazer valer uma outra imagem de si.

Portanto, até agora, os habitantes da vila não quiseram lutar pelo reconhecimento de uma identidade política dada - no caso, a de quilombola. Preferem se dizer empenhados na preservação e na promoção de um patrimônio cultural ou, melhor dizer, de vários patrimônios culturais separados. Esse projeto é compatível com a nova visão da sociedade brasileira incentivando a dissociar as diferentes "raízes", para restituir-lhes uma suposta "pureza" associada a cada um dos grupos que fundaram a nação. No entanto, relativa a práticas e não a pessoas, essa leitura tem efeitos bem diferentes, pois autoriza a transformação das "identidades étnicas", aqui por definição limitadoras, em bens culturais dos quais se pode dispor à vontade. Essa estratégia, mais cultural do que étnica, permite, por exemplo, a integração de novos patrimônios como o sairé, definido como dança indígena, sem que seja necessário apontar para a presença efetiva do tipo humano ao qual é associado. Vale notar que, se a dominante negra continuasse a prevalecer no Mazagão Velho, o sairé aparentar-se-ia mais à festa de São Tiago do que ao marabaixo do ponto de vista da sua inserção no discurso. De modo análogo, tratar-se-ia de um bem considerado como representativo de um tipo de população particular, defendido, promovido e protegido por um grupo reivindicando para si uma outra genealogia.

Será que essa representação da história no Mazagão, ao mesmo tempo metódica e aberta, seriando as linhagens numa cronologia, pode ser vista como uma "resposta" às políticas públicas atuais? $\bigcirc$ propósito do governo, ao instituir discriminações positivas para combater a desigualdade social enfrentada por certos grupos de população, é louvável, como são necessárias as denúncias do racismo que permeia a sociedade brasileira. Todavia, o que é tido como "libertação" e "conscientização", quando os "morenos" passam a se considerar negros quilombolas também pode ser interpretado como a imposição de um novo prisma, tão desvirtuador quanto o precedente, quando acreditava-se que negros e índios deviam tornar-se brancos. Ver o país como formado por grupos "etnoraciais" com contornos rígidos e fronteiras intransponíveis, lutando cada um para seu reconhecimento e a obtenção de direitos diferenciados, tem a desvantagem de negligenciar um questionamento mais sociológico sobre a permanência das estruturas de dominação, sobre os dispositivos e a dinâmica da reprodução de uma ordem social profundamente desigual - um dos dados fundamental desse viés analítica sendo que são tidos como "brancos" antes de 
tudo aqueles que têm poder aquisitivo, isto é, em função de critérios sócioeconômicos. E, desse ponto de vista, não há dúvida que o Mazagão Velho seja negro. Seja como for, lá se dispõe de pelos menos dois elementos "culturais" poderosos, de profundeza "histórica" equivalente, mas remetendo a genealogias diferentes, para marcar a sua especificidade frente aos outros povoados do Estado.

\section{Referências Bibliográficas}

Albuquerque, Marco. (2004), Prospecção Arqueológica em Mazagão Velho. Encaminhado a segunda superintendência regional do Iphan governo do Estado do Amapá, mimeo.

Amselle, Jean-Loup. (2001), Branchements : anthropologie de l'universalité des cultures. Paris: Flammarion.

Araújo, Hermano Benedito Pinto de, Canto, Fernando Pimentel, Monteiro, Herialdo Teixeira \& Silva, Alzira Nogueira da. (1999), "Mouros e Cristãos” em Mazagão Velho: práticas culturais e mudanças. Macapá: Monografia da Especialização em Desenvolvimento Sustentável e Gestão Ambiental, Centro de Formação e Desenvolvimento de Recursos Humanos - CEFORH.

Araújo, Renata Malcher de. (1998), As Cidades da Amazônia no Século XVIII: Belém, Macapá, Mazagão. Porto : Faup Edições. .

Freyre, Gilberto, (1933). Casa Grande $\mathcal{E}$ Senzala: formação da família brasileira sob o regime de economia patriarcal. Rio de Janeiro: Maia \& Schmidt.

GuZMÁn, Décio de Alencar. (2006), "Índios misturados, caboclos e curibocas: análise histórica de um processo de mestiçagem, Rio Negro (Brasil, séculos XVIII e XIX)”. In: C. AdAms, R. MurrietA, W. Neves Sociedades Caboclas Amazônicas: modenidade e invisibilidade. São Paulo: Annablume.

Lima, Deborah, AlEncAr, Edna Ferreira. (2001), "A lembrança da História: memória social, ambiente e identidade na várzea do Médio Solimões". Lusotopie 2001: 27-48.

Pereira, Manoel Nunes. (1989), O Sahiré e o Marabaixo. Recife: FUNDAJ, Massangana.

Treccani, Giramolo. (2006), Terras de Quilombo: caminhos e entraves do processo de titulação. Belém: Programa Raízes.

Vidal, Laurent. (2005), Mazagão, la ville qui traversa l'Atlantique: du Maroc à l'Amazonie (1769. 1783). Paris: Aubier.

WACHTEL, Nathan. (1990), Le retour des ancêtres: Les Indiens Urus de Bolivie, XXe-XVIe siècle (essai d'histoire régressive). Paris: Gallimard.

\section{Notas}

* Uma versão preliminar foi apresentado na 26‥ Reunião Brasileira de Antropologia, realizada entre os dias 01 e 04 de junho de 2008, Porto Seguro, Bahia, Brasil.

1 Entendo esses termos, bem como os de branco, quilombola, português etc. como categorias do discurso, por isto coloco entre aspas. No entanto, para facilitar a leitura, as aspas serão usadas só na sua primeira aparição no texto.

2 Essa perspectiva é próxima da proposta análitica de Jean-Loup Amselle : «privilegiando as relações sobre os elementos, as conexões sobre os pólos, renuncia-se desta forma a uma abordagem em termos de essências ou de substâncias» (2001 :206, tradução livre).

3 A não ser quando mencionarei referencias bibliográficas, as informações sobre a história e a cultura do Mazagão Velho remetem a versão dos habitantes. Não se pretende aqui proceder a uma historia regressiva (Wachtel 1990) para chegar a uma verdade cientifica, mas sim entender como esse tema do passado é tratado e o que diz sobre o grupo hoje - à maneira do mito que enuncia regras sociais.

4 Além de energia (1975), de uma antena telefônica e de um posto da Caesa, Mazagão Velho dispõe 
de uma escola, um posto de saúde, uma sub-prefeitura e conduções regulares para a capital e o Mazagão Novo. As atividades econômicas principais são o extrativismo (açaí, carvão) e o plantio de mandioca no assentamento do Incra. Consta também um alto número de funcionários federais, estaduais e municipais.

5 Para uma descrição detalhada das etapas da batalha, ver Araújo, Canto, Monteiro \& Silva (1999).

${ }^{6}$ O termo negro aparece no discurso para caracterizar a vila ou a "raça" predominante nela de modo geral, mas é pouco usado pelas pessoas para falar de si próprio, estas referindo-se com mais freqüência às palavras preto, pardo, moreno, etc. Como não cabe uma análise detalhada dos vários sentidos e das nuanças entre essas expressões pertencendo ao registro descritivo na discussão das representação das diferentes genealogias do Mazagão Velho, considero até mais ampla pesquisa que constituem declinações da categoria "negro", uma categoria política coletiva. Por isso, usarei aqui só este último termo.

7 O estatuto atribuído aqui ao marabaixo era perfeitamente congruente com a representação ideal da sociedade brasileira dada por Gilberto Freyre (1933) que, ao contrário do que se supõe geralmente, não é de democracia racial no sentido de igualdade. Tratava-se, numa complementaridade bem hierarquizada, de indicar que o fundamento incontestavelmente pensado como branco tinha acrescentado alguns elementos ornamentais africanos e ameríndios, portanto acessórios.

${ }^{8}$ Uma primeira, a União Folclórica, foi formada em 1992 e extinta em 2003.

9 Laurent Vidal (2005) informa que provavelmente São Tiago deixou de ser homenageado de 1777 até a fundação do Mazagão Novo, em 1915.

${ }^{10}$ Ver o trabalho do folclorista Nunes Pereira (1989) para uma descrição das danças do sairé e do marabaixo.

${ }^{11}$ Aceitam portanto a definição histórica do quilombo, aquela que é recusada pelos militantes - ver, por exemplo, G. Treccani (2006).

Recebido em abril de 2008 Aprovado em julho de 2008

\section{Véronique Boyer (veronique.boyer@free.fr)}

Diretora de Pesquisa do Centre National de la Recherche Scientifique (CNRS - França), desenvolveu pesquisas na Amazônia sobre os cultos afro-brasileiros e as igrejas evangélicas. Além de artigos em revistas especializadas, publicou dois livros: Femmes et cultes de possession au Brésil: les compagnons invisibles (Paris, L'Harmattan, 1993) e Expansion évangélique et migrations en Amazonie brésilienne: la renaissance des perdants (Paris, Karthala, 2008). Começou agora, ainda na região amazônica, um trabalho sobre as chamadas comunidades negras rurais. 


\section{Resumo:}

Através de um estudo de caso amazônico, o artigo propõe analisar como as orientações do Estado brasileiro, dizendo respeito ao caráter pluriétnico da sociedade, são elaboradas a nível local. Pois, os grupos sociais são agora incentivados a dar relevo a certas práticas culturais enquanto símbolos de identidades especificas. Quais são então os lugares atribuídos às genealogias concorrentes, doravante minoritárias? Como são ritualizadas e encenadas as diferenças culturais, étnicas e religiosas? Essas questões serão discutidas para uma vila amapaense que, através das suas festas, reivindica uma dupla ou talvez mesmo uma tripla herança: "portuguesa" com a festa católica de São Tiago, "negra" com a dança do marabaixo, e "índia" com a dança do sairê - esta última expressando atualmente um desejo, ainda não concretizado, de reativação.

Palavras-chave: identidade, cultura, Amazônia, negro, religião.

\section{Abstract:}

This article analyses through an Amazonian example how the multi-ethnic orientations of the Brazilian State are locally elaborated. The Brazilian State is now stimulating the promotion of new cultural practises and symbols of specific identities. What is happening with genealogical identities now less considered? How are they located? How the ethnic and cultural distinctions (or specificities) are ritualized and performed? These questions will be discussed through the festivities of a village from the Amapa proclaiming a double and perhaps triple inheritance: Portuguese, with the celebration of São Tiago, "Black", with the dance of the Marabaixo and "Indian", with the dance of the Saiê. The later actually is trying to be reactivated.

Keywords: identity, culture, Amazonia, negro, religion. 